\title{
色が画像の感情処理過程に及ぼす影響
}

\author{
黒原 玄弥・小川 景子 (広島大学大学院総合科学研究科)
}

\section{Effect of Color on Processing Emotional Pictures}

\author{
Genya Kurohara, Keiko Ogawa (Graduate School of Integrated Arts and Sciences, \\ Hiroshima University)
}

Color facilitates the processing of information in emotional pictures. Studies have reported that the amplitude of event-related potential's early posterior negativity (EPN) increases more when processing emotional pictures in color than in grayscale. In contrast, the effect of color on the late positive potential (LPP) amplitude is unclear. Color also facilitates perceiving the global properties of pictures. We investigated the effect of color on subjective and psychophysiological indices (EPN and LPP) under perceptually challenging conditions by manipulating the spatial frequency (low-pass pictures). Participants evaluated the valence of pictures (positive, neutral, or negative), and electroencephalograms were measured during the task. The results indicated that positive and neutral pictures in color were rated as more pleasant than in grayscale. Moreover, the EPN amplitudes increased for color than for grayscale images, regardless of the spatial frequency. However, no effect of color was observed on the LPP amplitude. These results suggest that color influences initial visual information processing of emotional pictures, regardless of the spatial frequency.

Key words: emotion, color, spatial frequency, late positive potential, early posterior negativity

【要 約】画像の色は, 感情画像によって喚起される感情の処理を促進させる。感情処理過程に関連する事象関 連電位について, 初期後頭陰性電位 (early posterior negativity: EPN) はモノクロ画像よりもカラー画像で振幅が 増大するのに対し, 後期陽性電位 (late positive potential: LPP) に対する色の影響は一貫していない。色は画像の 大域的な認識も容易にする。そこで本研究では, 画像内容の識別が困難な不鮮明画像（低周波通過処理画像）を 用いることで，画像の色が感情に関連する主観および生理指標（EPNとLPP）に影響を及ぼすか検討した。参加 者に対して, 快/中性/不快画像の感情価を判断する課題を実施し, 課題中の脳波を測定した。検討の結果, 快/ 中性画像では，カラー画像の方がモノクロ画像と比べ主観的に快と評定された。画像の鮮明性に関わらず， EPN 振幅はモノクロ画像よりもカラー画像で増大したのに対して, LPP振幅に色の影響は観察されなかった。本研究 結果から, 画像の色は, 画像の鮮明性に関係なく, 感情画像の初期の知覚を促進し, 感情画像の主観評定にも影 響を及ぼすことが明らかになった。

2020.4.6受稿，2020.11.2受理，2020.12.10 J-STAGE早期公開，doi: 10.5674/jjppp.2012oa

連絡者及び連絡先： $7739-8521$ 広島県東広島市鏡山一丁目 7番 1 号広島大学大学院総合科学研究科 小川景子

E-mail: ogawakeicom@hiroshima-u.ac.jp 
画像の色は画像の情報処理を促進する要因の一つとさ れる。これは, 画像の色が画像における輪郭線の抽出 (Gegenfurtner \& Rieger, 2000; Hansen \& Gegenfurtner, 2009) や画像に対する文脈処理（Elliot \& Maier, 2012; Hansen \& Gegenfurtner, 2009), 画像内容の理解 (Castelhano \& Henderson, 2008; Oliva \& Schyns, 2000）を促進させるためである。さらに, 画像の色は 画像に対する注意 (Itti \& Koch, 2000) やその画像の記 憶 (Gegenfurtner \& Rieger, 2000; Wichmann et al., 2002)を促し, 感情画像では画像に対する感情処理も促 進させる (Codispoti et al., 2012; Bekhtereva \& Müller, 2017)。このように, 画像の色は画像内容の理解を促 し, 画像に対する注意や記憶, 感情の処理にも影響を 及ぼす。

画像の色は, 感情と関連する事象関連電位 (eventrelated potential: ERP) にも影響を及ぼすことが分 かっている。感情画像との関連が報告されているERP として, 初期後頭陰性電位 (early posterior negativity: EPN) と後期陽性電位 (late positive potential: LPP) が ある。

EPNは, 頭頂後頭部優勢で, 刺激呈示後 $200 \mathrm{~ms}$ ら $300 \mathrm{~ms}$ に頂点をもつ陰性電位であり, 感情価を持 つ画像への注意配分量と関連する (Junghöfer et al., 2001; Olofsson et al., 2008; Schupp et al., 2006)。画 像の色とEPNの関連について, Bekhtereva \& Müller (2017) は, モノクロの感情画像と比べてカラーの感 情画像で振幅が増大したことから, 感情画像に対する 初期の視覚情報処理活動は, 色があることで増大する ことを示している。

LPPは, 後頭部優勢で刺激呈示後 $400 \mathrm{~ms}$ 以降に現 れる陽性電位である (Bradley, 2009; Codispoti et al., 2007; De Cesarei \& Codispoti, 2011a)。LPPは, 脳内 の感情処理過程と関連が示されており, 画像の感情価 と覚醒度の両方との関連が報告されている(Codispoti et al., 2009; Cuthbert et al., 2000; Feng et al., 2014; Ito et al., 1998; Lang et al., 1990; Schupp et al., 2006)。画像の色とLPPの関連について, Cano et al. （2009）は, 覚醒度を統制した感情画像を用いて, 画 像の色が感情画像に対する感情処理過程に及ぼす影響 を検討した。その結果, 画像呈示後 $300 \mathrm{~ms}$ から $500 \mathrm{~ms}$ に前頭部優勢に現れた陽性電位 (P300/LPP)に ついて, カラー画像では不快/中性画像と比べて快画
像で振幅が増大したが, モノクロ画像では有意差は得 られなかった。この結果から, Cano et al.(2009) は, 画像の色が画像の感情処理過程と関連するP300/LPPに 影響を及ぼすことを示唆した。しかし, 画像の色がLPP に影響を及ぼさないとする報告もあり (Bekhtereva \& Müller, 2017; Weymar et al., 2009), 画像の色が感情 処理過程に関連するLPPに影響を与えるか議論がな されている。

Codispoti et al. (2012) は, 知覚が困難な状況であ れば，画像の色の効果がより顕著にみられるのではな いかと指摘している。これは, 画像の色が画像の大域 的特性の一つであり (Castelhano \& Henderson, 2008), 画像の大域的特性は短時間呈示という知覚が困難な状 況でも画像内容の識別に重要な情報を与える (Schyns \& Oliva, 1994)ためである。Codispoti et al.(2012) は, 知覚が困難な状況を短時間呈示 $(24 \mathrm{~ms})$ でつくり 出し, 画像の色がLPPに及ぼす影響を検討した。検 討の結果, 呈示時間に関係なく, 感情的なカラー画像 とモノクロ画像の間でLPP振幅に差はみられなかっ た。つまり, 知覚が困難な状況でも, 画像の色の影響 はみられなかった。Codispoti et al. (2012)で画像の 色がLPPに及ぼす影響を観測できなかった理由とし て, 知覚が困難な状況を短時間呈示の操作ではつくり 出すことができなかった可能性が考えられる。go/ nogo 課題を用いた画像の分類課題では, 画像の呈示時 間が $20 \mathrm{~ms}$ でも，正答率は高い (Thorpe et al., 1996)。 さらにこの知見では, 認知的な制御が必要な nogo刺 激に対するERPも変化したため (Thorpe et al., 1996), 認知的課題を行うために必要な視覚情報処理 活動は, $20 \mathrm{~ms}$ 呈示でも可能といえる。感情画像を用 いた研究においても, 呈示時間を $25 \mathrm{~ms} ら 6000 \mathrm{~ms}$ までの8段階で変化させて検討を行ったが, LPPに呈 示時間の影響はみられなかった (Codispoti et al., 2009)。これらの知見を踏まえると, 画像の呈示時間 の操作で知覚が困難な状況をつくり出すことは難しい と考えられる。

知覚が困難な状況をつくり出すその他の要因とし て, 画像の空間周波数がある。画像の高周波带域は画 像における輪郭線の抽出といった細かな情報を与え, 低周波帯域は場面の構造といった大域的情報を私たち に与える (Kauffmann et al., 2014)。画像の色は, 画 像に打ける輪郭線の抽出を促す (Gegenfurtner \& 
Rieger, 2000; Hansen \& Gegenfurtner, 2009)。そのた め, 不鮮明な画像 (低周波通過処理画像) を知覚する 際, その色によって輪郭線の知覚が促進され, 感情処 理が容易になると考えられる。そこで, 本研究では, 画 像の空間周波数を操作することで鮮明性を制御し, 画 像の鮮明性によって知覚が困難な状況をつくり出す。

実際に, 感情画像の空間周波数が, 感情の主観評定 とERPに影響を及ぼすことが報告されている。画像 の空間周波数が低周波帯域のみになることで画像の鮮 明性は低下し, 快/中性/不快画像に対する感情価の主 観評定值の差が小さくなることが示されている $(\mathrm{De}$ Cesarei \& Codispoti, 2008)。低/高周波通過処理画像 の両方に対して, 処理をしていない画像と比べ, 初期 電位 (P1, N1, P2) の振幅 (De Cesarei et al., 2013) や LPP振幅 (De Cesarei \& Codispoti, 2011b) は減衰す る。以上より, 画像の空間周波数を操作して画像の鮮 明性を変化させることで, 感情画像に対する主観評定 や感情処理に関連するERPが変化し, 画像の色が LPPに及ぼす影響を観測できると考えられる。

まとめると, 本研究では, 画像の感情処理過程に画 像の色が及ぼす影響について明らかにする。そのため に, 知覚が困難な状況において, 感情処理過程に関連 する後期電位のLPPに画像の色が影響を及ぼすか検 討する。知覚が困難な状況は, 画像の空間周波数を用 いて操作する。併せて, 知覚が困難な状況において, 画像の色が感情画像に対する主観評定や感情と関連す る初期電位の EPNにも影響を及ぼすか検討する。

\section{方 法}

\section{参加者}

参加者は矯正視力を含む視力が正常な大学生 23 名 (女性 10 名, 男性 13 名) で, 平均年齢は 20.5 歳 $(S D=$ 0.9)であった。参加者には, 事前に実験に関する説明 を行い, 文書による実験参加への同意を得た。本研究 は, 広島大学大学院総合科学研究科倫理委員会の承諾 を得ている(承認番号01-62)。

\section{実験デザイン}

感情価（快/中性/不快）×色（カラー/モノクロ） $\times$ 鮮 明性 (鮮明/不鮮明)の三要因参加者内比較デザインと した。

\section{刺激・装置}

Figure 1 に使用した画像例を示す。International Affective Picture System(IAPS, Lang et al., 2008) と Web上のフリー画像から実験者が快画像40枚 (e.g., 猫, 子ども), 不快画像 40 枚 (e.g., 熊, 銃), 中性画 像 40 枚 (e.g., イス, 道路), 計 120 枚選出した。その 画像を視覚的評定尺度であるSelf-Assessment Manikin（SAM, Bradley \& Lang, 1994)を用いて, 大 学生・大学院生 10 名が感情価と覚醒度を9件法で評 定した（感情価, 不快 1 点一快 9 点; 覚醒度, 鎮静 1 点 一覚醒9点)。その結果から, 24枚ずつ各感情価の画 像を選定した (快画像 : 感情価, $M=7.05, S D=0.24$, 覚醒度, $M=4.93, S D=0.64$; 中性画像: 感情価, $M$ $=4.83, S D=0.23$, 覚醒度, $M=4.89, S D=1.29$; 不快 画像: 感情価, $M=3.09, S D=0.71$, 覚醒度, $M=$ $6.25, S D=1.06)$ 。感情価と覚醒度の主観評定值につ いて, 画像の感情価の一要因分散分析を行った。感情 価の主観評定值について, 画像の感情価の主効果があ り $\left(F(1.05,24.15)=1115.53, p<.01, \eta_{\mathrm{p}}^{2}=.98\right)$, 快画 像, 中性画像, 不快画像の順で有意に感情価の主観評 定值が低下した $(p \mathrm{~s}<.05)$ 。覚醒度の主観評定值につ いて, 画像の感情価の主効果があり $(F(2,46)=$ $\left.13.60, p<.01, \eta_{\mathrm{p}}^{2}=.37\right)$, 快/中性画像と比べ, 不快画 像で増大した $(p \mathrm{~s}<.05)$ 。

全ての画像がカラー画像であったため, Adobe社製 Adobe Photoshop CC (2015) を用いてモノクロ画像に
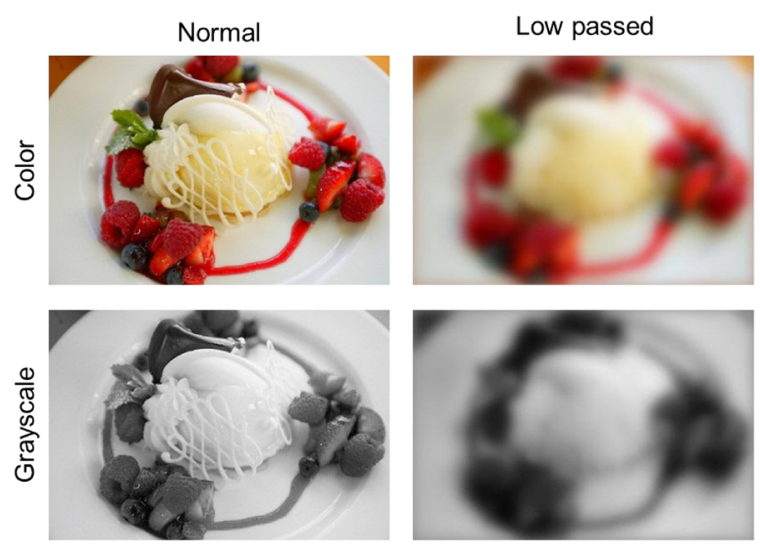

Figure 1. Sample stimuli for pleasant picture: Normal pictures are shown on the left and low pass pictures on the right, with color pictures shown in the upper section, and grayscale pictures in the lower section. 
変換した。空間周波数の操作には, 永山ら (1995) で 使用されたプログラムソフト (IMAGE)を用いた。永 山ら (1995) の研究より $6.2 \mathrm{c} / \mathrm{d}$ 以下の周波数を低周波 帯域とし，低周波帯域を取り出す操作を行った。

参加者に同じ画像を鮮明画像と不鮮明画像の両条件 で呈示した場合, 不鮮明画像に対する画像内容の識別 が容易になることが推測される。そのため，24枚の 画像を 4 条件 (カラー鮮明, カラー不鮮明, モノクロ 鮮明, モノクロ不鮮明) に振り分け, 1条件につき 6 枚呈示した。全ての感情画像（快, 中性, 不快)にお いて，4条件を6枚ずつ呈示するため，72枚の画像 セットを作成した。画像セットは参加者でカウンター バランスをとった。

課題は, 64 bit PC(DELL OPTIPLEX 9000)を使用 し，23インチの液晶ディスプレイ(DELL U2312HM) に呈示した。刺激は, 視角度が縦 $27.63^{\circ}$, 横 $36.33^{\circ}$ の 大きさで呈示した。

\section{主観指標}

SAMを用いて画像に対する感情価と覚醒度を評定 した。100 mmのVisual Analog Scale(VAS)を用い て, 課題中の気分, 眠気, モチベーション, 疲労度, 集中度を測定した。左端と右端に気分では「快-不 快」, 眠気では「眠い-眠くない」, モチベーションでは 「やる気が十分ある一やる気が出ない」, 疲労度では 「大変疲れている-まったく疲れていない」, 集中度で は「大変集中している-まったく集中していない」をそ れぞれ表記し, 参加者はその間に斜線を記した。評定 值は, 左端から参加者が記した斜線までの距離 (mm) とした。

\section{生理指標}

脳波は，国際 10-20法に基づき頭皮上 12 部位 (F3， F4, C3, C4, P3, P4, O1, O2, Fz, Cz, Pz, Oz) と右耳架 (A2)より, 左耳架 (A1) 基準で単極導出した。眼電図 は, 水平眼球運動を左右の眼角外より双極導出し, 垂 直眼球運動を左眼窩上下より双極導出した。ボディ アースは額に装着し, 電極は $\mathrm{Ag} / \mathrm{AgCl}$ 電極を用いた。 脳波と眼電図は, 脳波計 (株式会社デジテックス研究 所製脳波計Polymate AP1000）を用いて測定した。記 録時の時定数は 5 秒とし, ハイカットフィルタは $100 \mathrm{~Hz}$, サンプリング周波数は $500 \mathrm{~Hz}$ とした。
分析には, Brain Vision Analyzer (Brain Product製) を用いた。分析時に両耳架で再基準化を行い, $0.03 \mathrm{~Hz}$ か $30 \mathrm{~Hz}$ のバンドパスフィルタ $(12 \mathrm{~dB} / \mathrm{oct})$ をかけた。加算回数を確保するため, Gratton et al. (1983)の方法を用いて, 水平垂直眼球運動と瞬き による眼球運動を補正した。刺激呈示をトリガーとし て, 刺激呈示前 $300 \mathrm{~ms}$ から刺激呈示後 $1000 \mathrm{~ms}$ 区間 を加算平均し, 刺激呈示前 $300 \mathrm{~ms}$ から $0 \mathrm{~ms}$ の平均電 位を基準とした。

EPN振幅は, 画像の色とEPNの関連を検討した Bekhtereva \& Müller(2017)を参考に, P3, P4, O1, $\mathrm{O} 2$ 部位の平均波形を用いて, 画像刺激呈示後 $200 \mathrm{~ms}$ から $300 \mathrm{~ms}$ の区間平均電位とした。

LPP振幅は, 画像刺激呈示後 $400 \mathrm{~ms}$ から $800 \mathrm{~ms}$ の 区間平均電位とした。

EPN振幅とLPP振幅の区間平均電位の算出に関し て, 電流源密度 (current source density: CSD) 分析を 行い, 頭皮上分布の確認を行った。EPNはP3, P4, O1, O2 部位優勢に観察された。LPPは頭頂部優勢に 観察された。そのため, LPP振幅の検討にはPz部位 を用いた。また，画像の色の効果がみられたP300/ LPPの研究では, 前頭部で感情価の効果がみられてい るため (Cano et al., 2009), Fz部位も併せて検討し た。

加算回数は, 1 人当たり各条件 18 回であった。参加 者1名のみ, 実験不備により, カラー鮮明条件の中性 画像で加算が行えた試行の割合は89\%（16回), カ ラー不鮮明条件の快画像と中性画像で加算が行えた試 行の割合は94\%（17回）であった。その他の条件で 加算が行えた試行の割合は $100 \%$ （18回）であった。

\section{手続き}

実験概要を説明し同意を得た後，電極を装着した。 電極装着により低下した覚醒を通常の状態に戻すた め, 1 分間の計算課題を行った。その後, 一連の画像 がモニターに呈示されることを教示した。参加者に は，なるべく瞬きをしないように教示した。モニター に, 注視点が $2 \mathrm{~s}$ 呈示された後, 画像が $1 \mathrm{~s}$ 呈示され, 参加者は, 画像呈示後にボタン押しで快か不快か判断 した。これを 1 試行として 1 ブロック 72 試行, 合計 3 ブロック行った。呈示順序はランダムであり，3ブ ロックとも異なる呈示順序であった。参加者は 1 ブ 
ロックが終わるごとに課題中の主観評定について VASへ回答した。課題終了後, 再度画像を呈示し, SAMを用いて画像の感情価と覚醒度を評定した。

\section{統計分析}

統計分析にはSPSS statistics ver.22(IBM社製)を 用いた。VASで測定した気分，眠気，モチベーショ ン, 疲労度, 集中度について, ブロックの一要因分散 分析を行った。分析の結果, 疲労度でのみブロックの 主効果があり $\left(F(2,44)=7.83, p<.01, \eta_{\mathrm{p}}^{2}=.26\right), 1$ ブ ロック目と比べ3ブロック目で疲労度が増加した $(p<.01)$ 。これは, 課題遂行に伴う変化であり, 気分 などの主観的な変化がなかったことから, 本研究では 結果以降での記述を省略する。

$\mathrm{SAM}$ の感情価と覚醒度の主観評定值, EPN振幅 值，LPP振幅值それぞれについて，感情価（快/中性/ 不快), 色 (カラー/モノクロ ), 鮮明性 (鮮明/不鮮明) の三要因分散分析を行った。分散分析について, Mauchlyの球面性検定を行い, 球面性の仮定が成り 立たなかった場合, Greenhouse-Geisserの方法にお ける自由度調整を行った。分散分析で有意な効果が認 められた場合, Bonferroniの方法に基づく多重比較を 行った。分散分析において, 主効果および交互作用の 効果量は偏イータ2乗 $\left(\eta_{\mathrm{p}}^{2}\right)$ を記載した。有意水準は $p<.05$ とした。

\section{結 果}

\section{主観指標}

Table 1 にSAMの評定で得られた, 画像に対する感
情価と覚醒度の主観評定值を示す。感情価の主観評定 では, 感情価 $\times$ 色 $\times$ 鮮明性の交互作用は得られなかっ た $\left(F(2,44)=2.45, p=.10, \eta_{\mathrm{p}}^{2}=.10\right)$ 。感情価 $\times$ 色の 交互作用が得られ $\left(F(2,44)=15.73, p<.01, \eta_{\mathrm{p}}^{2}=.42\right)$ ， 単純主効果検定を行ったところ, カラー画像 $(F(2,21)$ $\left.=191.63, p<.01, \eta_{\mathrm{p}}^{2}=.95\right)$ とモノクロ画像 $(F(2,21)$ $\left.=104.69, p<.01, \eta_{\mathrm{p}}^{2}=.91\right)$ の両条件において, 快画 像, 中性画像, 不快画像の順で有意に感情価の主観評 定值が低下した $(p \mathrm{~s}<.05)$ 。また, 快画像 $(F(1,22)$ $\left.=110.77, p<.01, \eta_{\mathrm{p}}^{2}=.83\right)$, 中性画像 $(F(1,22)=$ $\left.14.74, p<.01, \eta_{\mathrm{p}}^{2}=.40\right)$ において，それぞれモノクロ 画像と比べカラー画像で感情価の主観評定值が増大し た。不快画像では, 有意差は得られなかった $\left(F(1,22)=0.44, p=.52, \eta_{\mathrm{p}}^{2}=.02\right)$ 。つまり, 快/中性 画像では, カラー画像の方が主観的に快と評定され た。感情価 $\times$ 鮮明性の交互作用が得られ $\left(F(1.53,35.76)=110.75, p<.01, \eta_{\mathrm{p}}^{2}=.83\right)$, 単純主効 果検定を行ったところ, 鮮明画像 $(F(2,21)=242.43$, $\left.p<.01, \eta_{\mathrm{p}}^{2}=.96\right)$ と不鮮明画像 $(F(2,21)=28.88, p$ $\left.<.01, \eta_{\mathrm{p}}^{2}=.73\right)$ の両条件に扔いて, 快画像, 中性画 像, 不快画像の順で有意に感情価の主観評定值が低下 した $(p \mathrm{~s}<.05)$ 。また, 快画像 $(F(1,22)=98.14, p$ $\left.<.01, \eta_{\mathrm{p}}^{2}=.82\right)$ と中性画像 $(F(1,22)=14.45, p<.01$, $\left.\eta_{\mathrm{p}}^{2}=.40\right)$ において, それぞれ不鮮明画像と比べ鮮明画 像で感情価の主観評定值が増大した。これに対して, 不快画像 $\left(F(1,22)=6.01, p<.05, \eta_{\mathrm{p}}^{2}=.21\right)$ では, 鮮 明画像と比べ不鮮明画像で感情価の主観評定值が増大 した。つまり, 快/中性画像では鮮明画像で主観的に快 と評定され，不快画像では鮮明画像で主観的に不快と 評定された。色 $\times$ 鮮明性の交互作用が得られ $(F(1,22)$

Table 1. Mean ratings of valence and arousal for each picture.

\begin{tabular}{|c|c|c|c|c|c|c|c|c|c|c|c|c|}
\hline & \multicolumn{4}{|c|}{ Pleasant pictures } & \multicolumn{4}{|c|}{ Neutral pictures } & \multicolumn{4}{|c|}{ Unpleasant pictures } \\
\hline & \multicolumn{2}{|c|}{ Color } & \multicolumn{2}{|c|}{ Grayscale } & \multicolumn{2}{|c|}{ Color } & \multicolumn{2}{|c|}{ Grayscale } & \multicolumn{2}{|c|}{ Color } & \multicolumn{2}{|c|}{ Grayscale } \\
\hline & Normal & LP & Normal & LP & Normal & LP & Normal & LP & ormal & LP & Normal & LP \\
\hline $\mathrm{V}_{\mathrm{c}}$ & $\begin{array}{c}8.03 \\
(0.53)\end{array}$ & $\begin{array}{c}5.40 \\
(1.63)\end{array}$ & $\begin{array}{c}7.06 \\
(0.98)\end{array}$ & $\begin{array}{c}3.47 \\
(1.10)\end{array}$ & $\begin{array}{c}5.43 \\
(0.98)\end{array}$ & $\begin{array}{c}4.39 \\
(1.13)\end{array}$ & $\begin{array}{c}4.85 \\
(1.17)\end{array}$ & $\begin{array}{c}3.81 \\
(1.07)\end{array}$ & $\begin{array}{c}2.83 \\
(0.80)\end{array}$ & $\begin{array}{c}3.31 \\
(0.83)\end{array}$ & $\begin{array}{c}2.74 \\
(1.06)\end{array}$ & $\begin{array}{c}3.13 \\
(0.90)\end{array}$ \\
\hline Arousal & $\begin{array}{c}5.94 \\
(1.41)\end{array}$ & $\begin{array}{c}4.34 \\
(0.90)\end{array}$ & $\begin{array}{c}5.15 \\
(1.14)\end{array}$ & $\begin{array}{c}3.64 \\
(1.12)\end{array}$ & $\begin{array}{c}5.50 \\
(1.30)\end{array}$ & $\begin{array}{c}4.17 \\
(1.20)\end{array}$ & $\begin{array}{c}5.43 \\
(1.53)\end{array}$ & $\begin{array}{c}3.89 \\
(0.97)\end{array}$ & $\begin{array}{c}6.83 \\
(1.17)\end{array}$ & $\begin{array}{c}4.81 \\
(1.30)\end{array}$ & $\begin{array}{c}6.60 \\
(1.01)\end{array}$ & $\begin{array}{c}4.06 \\
(1.56)\end{array}$ \\
\hline
\end{tabular}

Note. LP indicates low-pass filter. ( ) shows the standard deviations. 
$\left.=5.47, p<.05, \eta_{\mathrm{p}}^{2}=.20\right)$, $\quad$ カ 一画像 $(F(1,22)=$ $\left.18.29, p<.01, \eta_{\mathrm{p}}^{2}=.45\right)$ とモノクロ画像 $(F(1,22)=$ $\left.42.20, p<.01, \eta_{\mathrm{p}}^{2}=.66\right)$ の両条件において, 不鮮明画像 と比べ鮮明画像で感情価の主観評定值が増大した。つ まり，カラー/モノクロ画像に関わらず，鮮明画像の 方が主観的に快と評定された。また, 鮮明画像 $\left(F(1,22)=36.26, p<.01, \eta_{\mathrm{p}}^{2}=.62\right)$ と不鮮明画像 $\left(F(1,22)=79.12, p<.01, \eta_{\mathrm{p}}^{2}=.78\right)$ の両条件におい て, モノクロ画像と比べカラー画像で感情価の主観評 定值が増大した。つまり, 鮮明/不鮮明画像に関わら ず，カラー画像の方が主観的に快と評定された。画像 の感情価の主効果が得られ $(F(2,44)=293.39, p$ $\left.<.01, \eta_{\mathrm{p}}^{2}=.93\right)$, 下位検定の結果, 快画像, 中性画 像, 不快画像の順で感情価の主観評定値は有意に低下 した $(p \mathrm{~s}<.01)$ 。つまり, 快画像で主観的に最も快と 評定され，不快画像で主観的に最も不快と評定され た。また, 色 $\left(F(1,22)=131.70, p<.01, \eta_{\mathrm{p}}^{2}=.86\right)$ と 鮮明性 $\left(F(1,22)=30.85, p<.01, \eta_{\mathrm{p}}^{2}=.58\right)$ の主効果 が得られた。モノクロ画像よりもカラー画像で感情価 の主観評定值が増大し, 不鮮明画像よりも鮮明画像で 感情価の主観評定值が増大した。つまり，モノクロ画 像よりもカラー画像で主観的に快と評定され, 不鮮明 画像よりも鮮明画像で主観的に快と評定された。

覚醒度の主観指標では, 感情価 $\times$ 色 $\times$ 鮮明性 $\left(F(1.31,28.82)=0.35, p=.62, \eta_{\mathrm{p}}^{2}=.02\right)$, 感情価 $\times$ 色 $\left(F(2,44)=2.52, p=.09, \eta_{\mathrm{p}}^{2}=.10\right)$ の交互作用は得ら れなかった。感情価 $\times$ 鮮明性の交互作用が得られ $\left(F(2,44)=5.04, p<.05, \eta_{\mathrm{p}}^{2}=.19\right)$, 単純主効果検定 を行ったところ, 快画像 $\left(F(1,22)=30.32, p<.01, \eta_{\mathrm{p}}^{2}\right.$ $=.58)$, 中性画像 $\left(F(1,22)=61.77, p<.01, \eta_{\mathrm{p}}^{2}=.74\right)$, 不快画像 $\left(F(1,22)=60.59, p<.01, \eta_{\mathrm{p}}^{2}=.73\right)$ に打いて, それぞれ不鮮明画像と比べ鮮明画像で覚醒度の主観評 定值が増大した。また, 鮮明画像 $(F(2,21)=22.60$, $\left.p<.01, \eta_{\mathrm{p}}^{2}=.68\right)$ において, 快/中性画像よりも不快画 像で覚醒度の主観評定值が増大した $(p s<.01)$ 。色 $\times$ 鮮 明性の交互作用は得られなかった $(F(1,22)=3.45, p$ $\left.=.08, \eta_{\mathrm{p}}^{2}=.14\right)$ 。感情価 $(F(1.53,33.63)=14.97, p<.01$, $\left.\eta_{\mathrm{p}}^{2}=.41\right)$, 色 $\left(F(1,22)=16.42, p<.01, \eta_{\mathrm{p}}^{2}=.43\right)$, 鮮 明性 $\left(F(1,22)=72.60, p<.01, \eta_{\mathrm{p}}^{2}=.77\right)$ の主効果が得 られた。下位検定の結果, 快/中性画像と比べ不快画 像で覚醒度の主観評定值が増大した $(p s<.05)$ 。また, モノクロ画像と比べカラー画像, 不鮮明画像と比べ鮮
明画像で覚醒度の主観評定がそれぞれ増大した。

\section{EPN振幅}

Figure 2にEPN振幅を算出した各条件のERP波形 と区間平均電位を用いたCSDマップを示す。EPN振 幅値では, 感情価 $\times$ 色 $\times$ 鮮明性の交互作用は得られな かった $\left(F(1.57,34.54)=0.53, p=.55, \eta_{\mathrm{p}}^{2}=.02\right)$ 。感 情価 $\times$ 色 $\left(F(2,44)=0.48, p=.62, \eta_{\mathrm{p}}^{2}=.02\right)$, 感情価 $\times$ 鮮明性 $\left(F(2,44)=0.05, p=.95, \eta_{\mathrm{p}}^{2}<.01\right)$, 色 $\times$ 鮮 明性 $\left(F(1,22)=0.24, p=.63, \eta_{\mathrm{p}}^{2}=.01\right)$ の交互作用も 得られなかった。感情価の主効果も同様に得られな かった $\left(F(2,44)=0.15, p=.86, \eta_{\mathrm{p}}^{2}<.01\right)$ 。色の主効 果が得られ $\left(F(1,22)=6.08, p<.05, \eta_{\mathrm{p}}^{2}=.22\right)$, モノ クロ画像 $(M=0.80 \mu \mathrm{V}, S D=1.39)$ と比べカラー画像 $(M=0.59 \mu \mathrm{V}, S D=1.41)$ で振幅が増大した。鮮明性の 主効果も得られ $\left(F(1,22)=79.83, p<.01, \eta_{\mathrm{p}}^{2}=.78\right)$, 不鮮明画像 $(M=1.25 \mu \mathrm{V}, S D=1.17)$ よりも鮮明画像 $(M=0.14 \mu \mathrm{V}, S D=1.40)$ で振幅が増大した。

\section{LPP振幅}

Figure 3 にLP振幅を算出した各条件のERP波形と 区間平均電位を用いたCSDマップを示す。Pz部位に おけるLPP振幅值では, 感情価 $\times$ 色 $\times$ 鮮明性の交互作 用は得られなかった $\left(F(2,44)=0.27, p=.77, \eta_{\mathrm{p}}^{2}=.01\right)$ 。 感情価 $\times$ 色 $\left(F(2,44)=0.86, p=.43, \eta_{\mathrm{p}}^{2}=.04\right)$, 感情価 $\times$ 鮮明性 $\left(F(2,44)=2.76, p=.08, \eta_{\mathrm{p}}^{2}=.11\right)$, 色 $\times$ 鮮明性 $\left(F(1,22)=3.26, p=.09, \eta_{\mathrm{p}}^{2}=.13\right)$ の交互作用も得られな かった。感情価 $\left(F(1.60,35.12)=0.69, p=.48, \eta_{\mathrm{p}}^{2}=\right.$ $.03)$ と色 $\left(F(1,22)=0.01, p=.91, \eta_{\mathrm{p}}^{2}<.01\right)$ の主効果 も同様に得られなかった。鮮明性の主効果が得られ $\left(F(1,22)=31.69, p<.01, \eta_{\mathrm{p}}^{2}=.59\right)$, 不鮮明画像 $(M$ $=0.29 \mu \mathrm{V}, S D=0.57)$ よりも鮮明画像 $(M=0.74 \mu \mathrm{V}$, $S D=0.54$ )で振幅が増加した。

Fz部位における LPP振幅值でも同様に, 感情価 $\times$ 色 $\times$ 鮮明性 $\left(F(2,44)=0.04, p=.97, \eta_{\mathrm{p}}^{2}<.01\right)$, 感情 価 $\times$ 色 $\left(F(2,44)=0.04, p=.96, \eta_{\mathrm{p}}^{2}<.01\right)$, 感情 $\times$ 鮮 明性 $\left(F(2,44)=0.78, p=.47, \eta_{\mathrm{p}}^{2}=.03\right)$, 色 $\times$ 鮮明性 $\left(F(1,22)=2.59, p=.12, \eta_{\mathrm{p}}^{2}=.11\right)$ の交互作用は得ら れなかった。感情価 $\left(F(2,44)=1.50, p=.23, \eta_{\mathrm{p}}^{2}=.06\right)$ と色 $\left(F(1,22)=0.37, p=.55, \eta_{\mathrm{p}}^{2}=.02\right)$ の主効果も得 られなかった。鮮明性の主効果が得られ $(F(1,22)=$ $\left.8.96, p<.01, \eta_{\mathrm{p}}^{2}=.29\right)$, 不鮮明画像 $(M=-0.41 \mu \mathrm{V}$, 

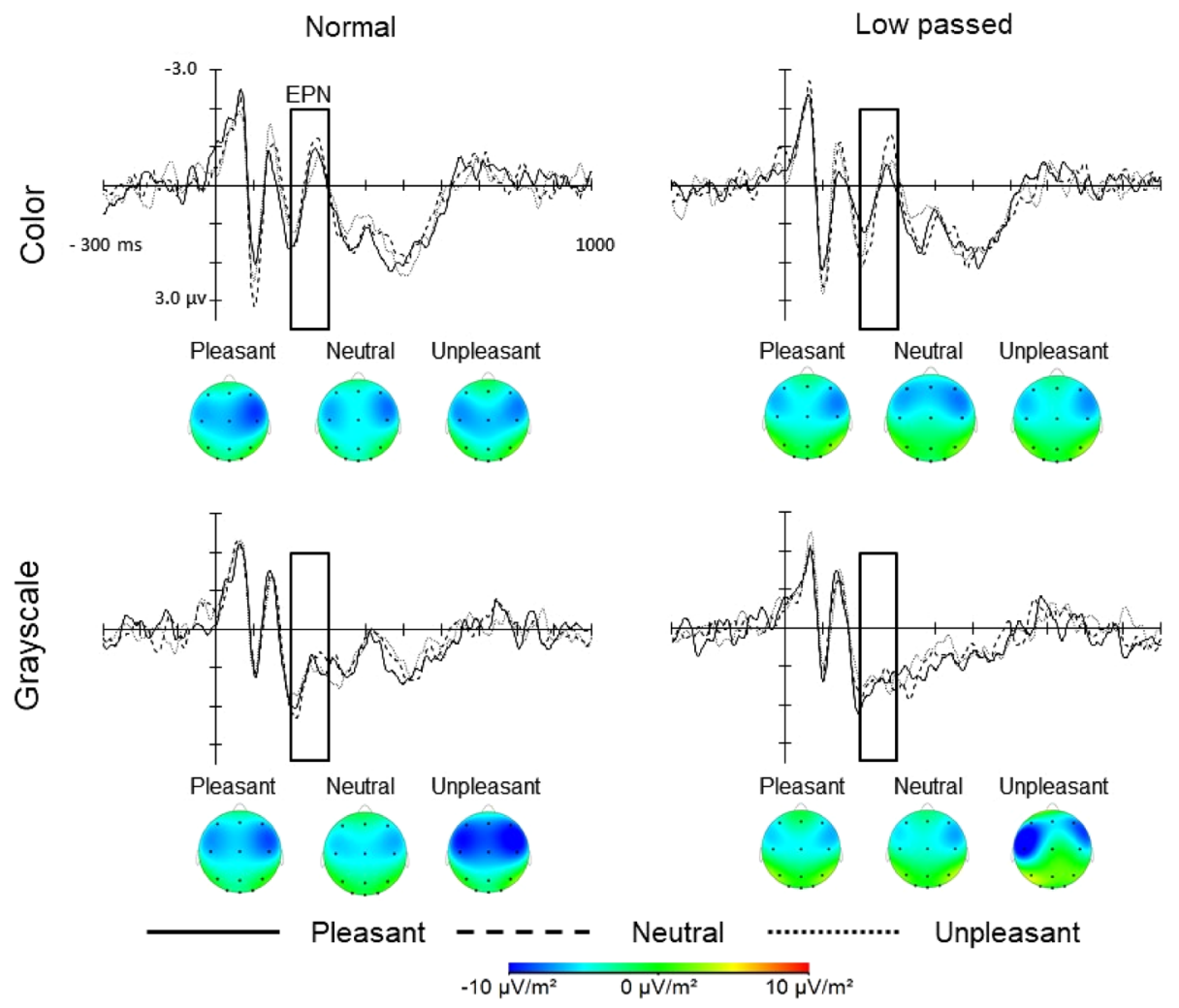

Figure 2. Grand-average ERP waveforms at parieto-occipital(P3, P4, O1, O2) cluster, and current source density (CSD) maps for pleasant, neutral, and unpleasant pictures: Normal pictures are shown on the left and low pass pictures on the right, with color pictures shown in the upper section, and grayscale pictures in the lower section.

$S D=0.84)$ より鮮明画像 $(M=-0.03 \mu \mathrm{V}, S D=0.91)$ で振幅が増大した。

\section{考 察}

本研究の目的は, 画像の感情処理過程に画像の色が 及ぼす影響について明らかにすることであった。その ために, 知覚が困難な状況において, 感情処理過程と 関連する後期電位のLPPに画像の色が影響を及ぼす か検討した。知覚が困難な状況は, 画像の空間周波数 を用いて操作した。また，知覚が困難な状況におい て, 画像の色が感情画像に対する主観評定や感情と関 連する初期電位のEPNにも影響を及ぼすか併せて検 討した。

検討の結果，鮮明性に関わらず，感情画像による LPPに画像の色が及ぼす影響は得られなかった。つま り, 知覚が困難な状況において, 画像の色はLPPへ 影響を及ぼさなかった。この結果は短時間呈示により 知覚が困難な状況を設定したCodispoti et al. (2012)
の研究と一致するものであった。先行研究において, 感情処理過程に関連するLPPに画像の色が及ぼす影 響は，知覚が困難な状況かどうかに関係なく観察され ていない (Bekhtereva \& Müller, 2017; Codispoti et al., 2012; Weymar et al., 2009)。感情画像に対する LPP 振幅は，画像の物理特性に関するボトムアップの 知覚要因の影響を受けない（画像の複雑性, Bradley et al., 2007; 画像サイズ, De Cesarei \& Codispoti, 2011a)。以上より, 画像の色は, 画像の物理特性に 関するボトムアップの知覚要因であるため, 知覚が困 難な状況かどうかに関係なく, 画像の色の効果はLPP にみられないと考えられる。本研究で得られたその他 の結果として, 画像の色は主観評定, EPN と関連が みられ，画像の鮮明性は主観評定， EPN, LPP と関連 がみられた。

\section{画像の色が主観評定とEPNに及ぼす影響}

本研究では，画像の色がLPPに及ほす影響は観測 されなかったが，主観指標と EPNへ及ぼす影響がみ 
(a) $\mathrm{Pz}$
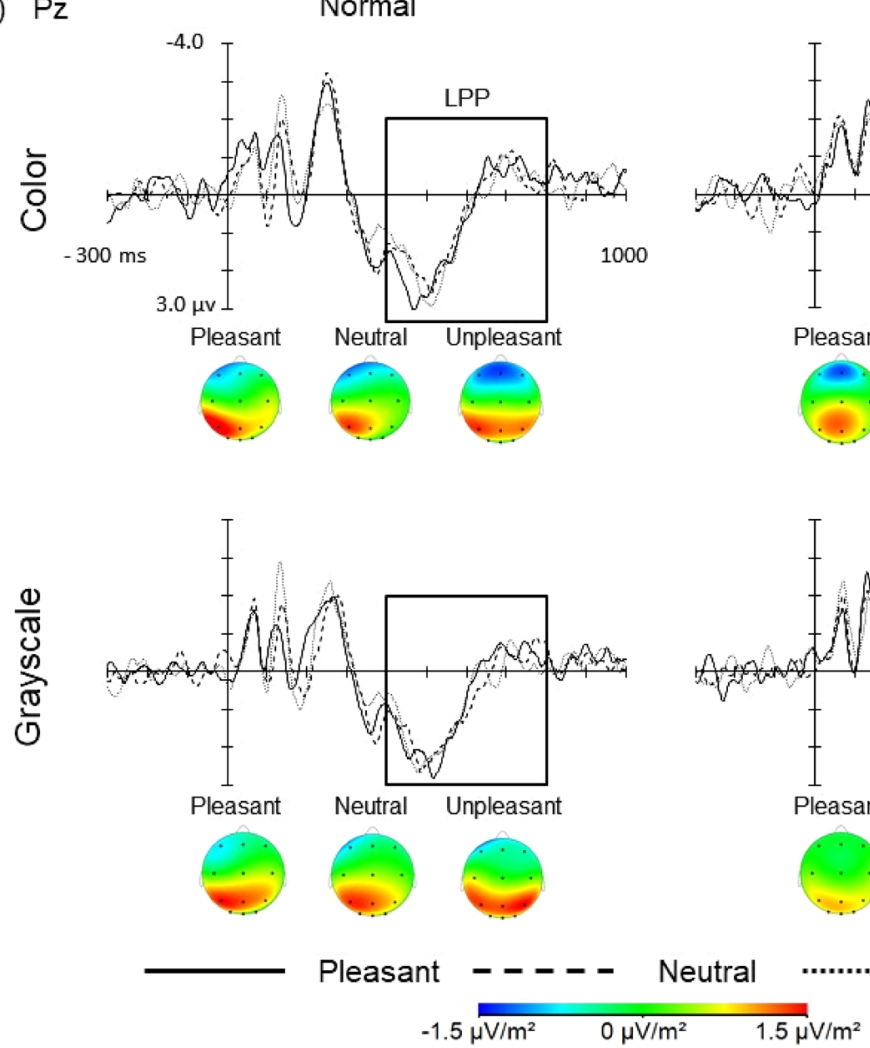

(b) $\mathrm{Fz}$
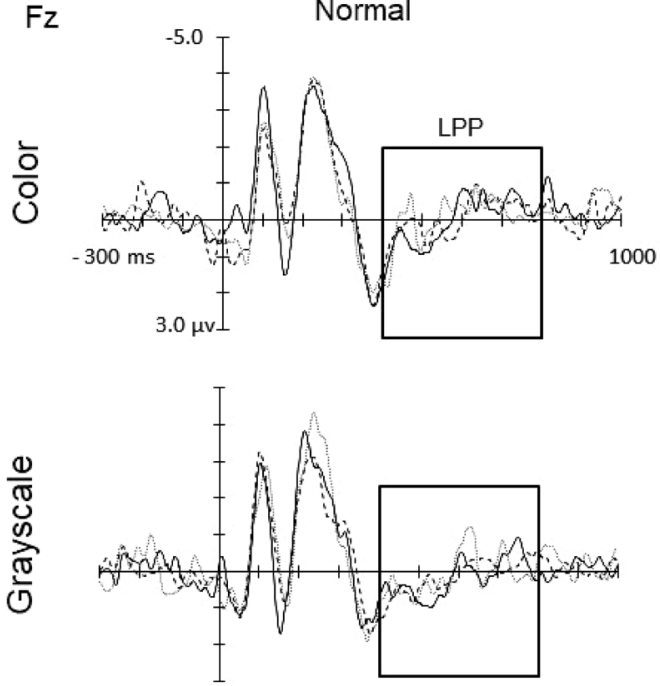

Pleasant
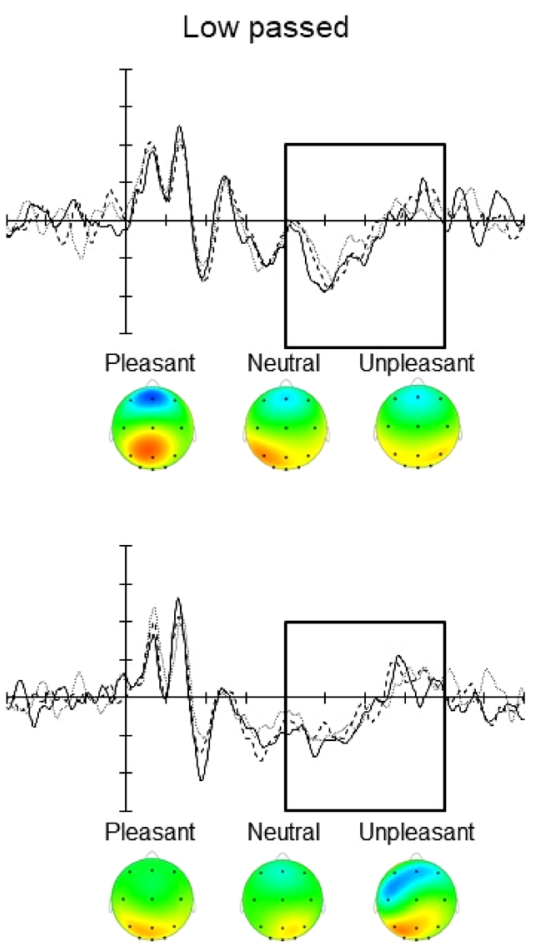

Unpleasant Low passed
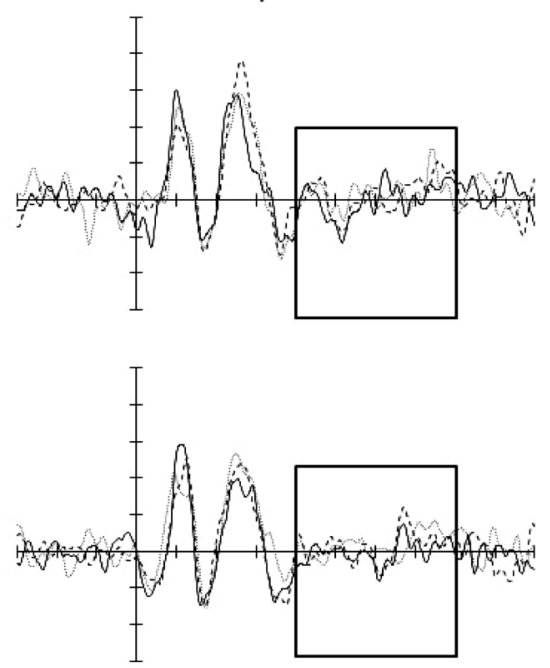

Neutral

Unpleasant

Figure 3. (a) Grand-average ERP waveforms at Pz and current source density (CSD) maps for pleasant, neutral, and unpleasant pictures, and (b) Grand-average ERP waveforms at Fz: Normal pictures are shown on the left and low pass pictures on the right, with color pictures shown in the upper section, and grayscale pictures in the lower section.

られた。本研究の主観評定では, 快/中性画像におい て, モノクロ画像よりもカラー画像で快と評定され た。覚醒度もカラー画像で増大した。画像の色は, 画 像の情報処理を促進するため (Elliot \& Maier, 2012;
Hansen \& Gegenfurtner, 2009; Itti \& Koch, 2000), 本研究でもカラー画像で画像の情報処理が促進したと 考えられる。本研究において, EPN振幅はモノクロ 画像と比べカラー画像で増大した。先行研究より, 
EPNが感情価を持つ画像への注意配分量と関連する ことが示されている (Junghöfer et al., 2001; Olofsson et al., 2008; Schupp et al., 2006)。以上の結果より, 画像の色はEPNに反映される初期の視覚情報処理活 動を促進させ, 主観評定に影響を及ぼしと示唆でき る。

画像の色が初期の視覚情報処理活動へ影響すること は定常状態視覚誘発電位 (steady state visual evoked potentials: SSVEP) を用いた知見でも報告されてい る。Bekhtereva \& Müller (2017) は, フリッカー刺激 と感情画像 (カラー/モノクロ) を同時に呈示すること で, SSVEPが画像の色の有無に影響を受けるか検討 した。SSVEPはフリッカー刺激の呈示に合わせて誘 発されることから，フリッカー刺激に対する注意量を 連続的に計測できる (Hindi Attar et al., 2010; Müller et al., 2011)。検討の結果, 色の有無に関係なく, 中 性画像に比べ不快画像でフリッカー刺激に対する SSVEP振幅は減衰し, さらに, モノクロ画像と比べ カラー画像呈示時において, SSVEP振幅の減衰時間 がより長く続いた (Bekhtereva \& Müller, 2017)。つ まり, 中性画像と比べ不快画像では, フリッカー刺激 よりも画像刺激に注意が向き, カラー画像の方がその 注意をより長く惹きつけたといえる（Bekhtereva \& Müller, 2017)。EPN とSSVEPの知見より, 画像の色 は初期の視覚情報処理活動へ影響すると考えられ, 本 研究結果もそれを支持する。

\section{画像の鮮明性が主観評定と EPN，LPPに及ぼす影響}

本研究では, 画像の色だけでなく, 空間周波数が感 情処理に及ほす影響もみられた。本研究において, EPN振幅は不鮮明画像より鮮明画像で増大した。EPN は感情価を持つ画像への注意配分量と関連するため (Junghöfer et al., 2001; Olofsson et al., 2008; Schupp et al., 2006), 本研究でも鮮明画像で刺激に対する注意が 促進されたと考えられる。本研究において, LPP振幅 は不鮮明画像より鮮明画像で増大した。De Cesarei \& Codispoti (2011b) は，画像の空間周波数に関係なく, 画像内容の識別が初めて可能だった空間周波数帯域の 画像においてLPP振幅が最大になることを示している。 この結果から, De Cesarei \& Codispoti (2011b)は, LPP は画像の空間周波数ではなく, 画像内容の識別の 程度によって, その振幅が増減すると示唆した。この
知見から, 本研究でも不鮮明画像よりも鮮明画像で画 像内容の識別がより容易であったと推察できる。本研 究に扔いて, 快/中性画像では, 不鮮明画像よりも鮮 明画像でより主観的に快と評定され, 不快画像では不 鮮明画像よりも鮮明画像でより主観的に不快と評定さ れた。ERPの知見を踏まえると, 鮮明画像は, 画像 内容の識別が容易であったため, より多くの注意が向 けられ，快画像と不快画像における主観評定值の差が 大きくなったと考えられる。

LPPが動機づけを喚起する刺激の知覚と関連するこ とが報告されている (Sabatinelli et al., 2013; Schupp et al., 2000)。またLPPの頭皮上分布について, LPP と動機づけを喚起する刺激の知覚との関連を検討した 研究では, 前頭部から頭頂部の広範囲でLPP との関連 が示されている (Ferrari et al., 2008; Gable \& Poole, 2014; Schupp et al., 2000)。本研究では, 画像の鮮明 性に関する影響は前頭部と頭頂部でみられた。これら のLPPに関する知見を踏まえると, 鮮明画像は画像 内容の識別を促進するだけでなく, 動機づけを喚起す る画像の知覚を促し, 画像に対する主観評定を促進さ せると示唆できる。

\section{刺激の覚醒度と LPP}

LPPは画像の覚醒度とも関連し, 中性画像と比べ 快/不快画像呈示時にその振幅は増大する (Bradley, 2009; Codispoti et al., 2007)。しかし, 本研究では, 不快画像で覚醒度の主観評定值が増大したが, 中性画 像と快/不快画像ではLPP振幅に差はみられなかった。 この理由として, 本研究とCodispoti et al.(2012) で は, 用いた画像内容が異なることが挙げられる。本研 究では, 倫理的観点から, Codispoti et al. (2012) で用 いられた性的な画像や人体が切断されている画像は含 めなかった。これらの画像は, 他の画像内容で構成さ れた快/不快画像と比べ, 覚醒度が高く評定され (Bradley et al., 2001), LPP振幅が増大する (De Cesarei \& Codispoti, 2011a)。本研究で用いた画像 は, Codispoti et al. (2012) で用いられた画像と比べ画 像の覚醒度が低かったため, 中性画像と比べ快/不快 画像に対してLPP振幅が増大しなかった可能性が考 えられる。

先行研究では画像の覚醒度がLPPに影響したのに 対して (Bradley, 2009; Codispoti et al., 2007), 本研 
究では画像の覚醒度の高低でLPPは変化しなかった。 これらの知見より, 画像の覚醒度や感情価とLPP と の関連は独立ではないことが推察される。実際に, 画 像の感情価の効果は画像の覚醒度の高低によって変化 すると考えられている (Cacioppo \& Berntson, 1994)。 Feng et al. (2014) では, 画像に対する覚醒度の主観評 定值が高い場合, 快画像と比べ不快画像でLPP振幅 が増大したが, 低い場合, 不快画像と比べ快画像で LPP振幅が増大した。本研究の主観指標でも, 快/中 性画像において, モノクロ画像と比べカラー画像は主 観的に快と評定された。これは, 覚醒度の主観評定値 が比較的低い画像であったため, 不快画像よりも快画 像で主観評定への色の影響がみられた結果と考えられ る。これらの知見と本研究結果から, 画像の覚醒度や 感情価とLPPとの関連は独立ではなく, 相互に関連 する可能性が示唆される。今後は, 快/不快画像でよ り覚醒度の主観評定值が高い画像を用いるなど刺激の 選定を再度行い検討する必要があると考えられる。

\section{本研究の限界}

本研究の限界点として, 参加者と画像の選定が挙げ られる。参加者について, 本研究では参加者の色覚異 常についての確認を行っていない。画像の色の知覚に ついて個人差があった可能性があり, 色覚についての 確認を行うべきであった。

次に画像の選定について, 単一の対象と背景のみの 画像を呈示するよりも, 複雑な場面の画像を呈示した 方が刺激呈示後 $150 \mathrm{~ms}$ から $250 \mathrm{~ms}$ の後頭部における 電位が陰性方向に増大することが示されている (Bradley et al., 2007)。本研究では, 知覚的な複雑性 の統制を行っていないため, EPNに関する結果が画 像の構成内容によって影響を受けている可能性が考え られる。今後, 感情画像を用いる場合は, 画像の情報 量の統制も行う必要があると考えられる。

\section{今後の展望}

画像の色が画像内容の判断に積極的に関与する画像 （e.g., 森林，砂漠）を用いた場合，不鮮明になると， モノクロ画像と比べ, カラー画像で画像内容の識別成 績が向上した (Oliva \& Schyns, 2000)。この知見を踏 まえ, 今後は, 感情画像の処理における画像の色の効 果を検討するため, 画像の色が画像内容の判断に積極
的に関与する感情画像を用いた課題を行う必要がある と考えられる。これらの画像を使うことで, 画像の色 がもつ文脈効果や, 初期の画像知覚における輪郭線の 効果が促進されると予測される。以上の検討より, 画 像の色がLPPに及ぼす影響の再検討が期待できる。

\section{まとめ}

本研究結果から, 知覚が困難な状況において, 画像 の色は後期電位であるLPPが関連する脳内の感情処 理過程ではなく, 初期電位である EPNが関連する視 覚情報処理活動を促進させたことが示唆された。さら に, 快/中性画像では, 画像の鮮明性に関わらず, カ ラー画像の方がモノクロ画像と比べ主観的に快と評定 された。そのため, 画像の色は, 画像の鮮明性に関わ らず, 感情画像の初期の知覚を促進させ, 感情画像の 主観評定にも影響を及ぼすことが明らかになった。

\section{引用文献}

Bekhtereva, V., \& Müller, M. M. (2017). Bringing color to emotion: The influence of color on attentional bias to briefly presented emotional images. Cognitive, Affective, \& Behavioral Neuroscience, 17, 1028-1047.

Bradley, M. M. (2009). Natural selective attention: Orienting and emotion. Psychophysiology, 46, $1-11$.

Bradley, M. M., Codispoti, M., Cuthbert, B. N., \& Lang, P. J. (2001). Emotion and motivation I: Defensive and appetitive reactions in picture processing. Emotion, 1, 276-298.

Bradley, M. M., Hamby, S., Löw, A., \& Lang, P. J. (2007). Brain potentials in perception: picture complexity and emotional arousal. Psychophysiology, 44, 364-373.

Bradley, M. M., \& Lang, P. J. (1994). Measuring emotion: The self-assessment manikin and the semantic differential. Journal of Behavior Therapy and Experimental Psychiatry, 25, 49-59.

Cacioppo, J. T., \& Berntson, G. G. (1994). Relationship between attitudes and evaluative space: A critical review, with emphasis on the separability 
of positive and negative substrates. Psychological Bulletin, 115, 401-423.

Cano, M. E., Class, Q. A., \& Polich, J. (2009) . Affective valence, stimulus attributes, and P300: Color vs. black/white and normal vs. scrambled images. International Journal of Psychophysiology, 71, 17-24.

Castelhano, M. S., \& Henderson, J. M. (2008). The influence of color on the perception of scene gist. Journal of Experimental Psychology: Human Perception and Performance, 34, 660-675.

Codispoti, M., De Cesarei, A., \& Ferrari, V. (2012). The influence of color on emotional perception of natural scenes. Psychophysiology, 49, 11-16.

Codispoti, M., Ferrari, V., \& Bradley, M. M. (2007). Repetition and ERPs: Distinguishing between early and late processes in affective picture perception. Journal of Cognitive Neuroscience, 19, 577-586.

Codispoti, M., Mazzetti, M., \& Bradley, M. M. (2009). Unmasking emotion: Exposure duration and emotional engagement. Psychophysiology, 46, 731-738.

Cuthbert, B. N., Schupp, H. T., Bradley, M. M., Birbaumer, N., \& Lang, P. J. (2000). Brain potentials in affective picture processing: covariation with autonomic arousal and affective report. Biological Psychology, 52, 95-111.

De Cesarei, A., \& Codispoti, M. (2008). Fuzzy picture processing: Effects of size reduction and blurring on emotional processing. Emotion, 8, 352-363.

De Cesarei, A., \& Codispoti, M. (2011a). Affectiv emodulation of the LPP and $\alpha$-ERD during picture viewing. Psychophysiology, 48, 1397-1404.

De Cesarei, A., \& Codispoti, M. (2011b). Scene identification and emotional response: Which spatial frequencies are critical? Journal of Neuroscience, 31, 17052-17057.

De Cesarei, A., Mastria, S., \& Codispoti, M. (2013). Early spatial frequency processing of natural images: An ERP study. PloS ONE, 8, e65103.
Elliot, A. J., \& Maier, M. A. (2012). Color in context theory. Advances in Experimental Social Psychology, 45, 61-125.

Feng, C., Li, W., Tian, T., Luo, Y., Gu, R., Zhou, C., \& Luo, Y. J. (2014). Arousal modulates valence effects on both early and late stages of affective picture processing in a passive viewing task. Social Neuroscience, 9, 364-377.

Ferrari, V., Codispoti, M., Cardinale, R., \& Bradley, M. M. (2008). Directed and motivated attention during processing of natural scenes. Journal of Cognitive Neuroscience, 20, 1753-1761.

Gable, P. A., \& Poole, B. D. (2014). Influence of trait behavioral inhibition and behavioral approach motivation systems on the LPP and frontal asymmetry to anger pictures. Social Cognitive and Affective Neuroscience, 9, 182-190.

Gegenfurtner, K. R., \& Rieger, J. (2000). Sensory and cognitive contributions of color to the recognition of natural scenes. Current Biology, 10, 805-808.

Gratton, G., Coles, M. G. H., \& Donchin, E. (1983). A new method for off-line removal of ocular artifact. Electroencephalography and Clinical Neurophysiology, 55, 468-484.

Hansen, T., \& Gegenfurtner, K. R. (2009). Independence of color and luminance edges in natural scenes. Visual Neuroscience, 26, 35-49.

Hindi Attar, C., Andersen, S. K., \& Müller, M. M. (2010). Time course of affective bias in visual attention: Convergent evidence from steady state visual evoked potentials and behavioral data. NeuroImage, 53, 1326-1333.

Ito, T. A., Larsen, J. T., Smith, N. K., \& Cacioppo, J. T. (1998). Negative information weighs more heavily on the brain: the negativity bias in evaluative categorizations. Journal of Personality and Social Psychology, 75, 887-900.

Itti, L., \& Koch, C. (2000). A saliency-based search mechanism for overt and covert shifts of visual attention. Vision Research, 40, 1489-1506.

Junghöfer, M., Bradley, M. M., Elbert, T. R., \& Lang, P. J. (2001). Fleeting images: a new look at early 
emotion discrimination. Psychophysiology, 38, 175-178.

Kauffmann, L., Ramanoël, S., \& Peyrin, C. (2014). The neural bases of spatial frequency processing during scene perception. Frontiers in Integrative Neuroscience, 37, 1-14.

Lang, P. J., Bradley, M. M., \& Cuthbert, B. N. (2008). International affective picture system (IAPS) : Affective ratings of pictures and instruction manual. Technical Report A-8. Gainesville, FL: University of Florida.

Lang, S. F., Nelson, C. A., \& Collins, P. F. (1990). Event-related potentials to emotional and neutral stimuli. Journal of Clinical and Experimental Neuropsychology, 12, 946-958.

Müller, M. M., Andersen, S. K., \& Hindi Attar, C. (2011). Attentional bias to briefly presented emotional distractors follows a slow time course in visual cortex. Journal of Neuroscience, 31, 15914-15918.

永山 ルッ子・吉田 弘司・利島 保 (1995). 顔表象と 既知性の相互関連性一一顔画像の空間周波数特性 の操作と倒立呈示法を用いた分析一 心理学研 究, 66, 327-335.

Oliva, A., \& Schyns, P. G. (2000). Diagnostic colors mediate scene recognition. Cognitive Psychology, 41, 176-210.

Olofsson, J. K., Nordin, S., Sequeira, H., \& Polich, J. (2008). Affective picture processing: an integrative review of ERP findings. Biological Psycholo$g y, 77,247-265$.
Sabatinelli, D., Keil, A., Frank, D. W., \& Lang, P. J. (2013). Emotional perception: Correspondence of early and late event-related potentials with cortical and subcortical functional MRI. Biological Psychology, 92, 513-519.

Schupp, H. T., Cuthbert, B. N., Bradley, M. M., Cacioppo, J. T., Ito, T. \& Lang, P. J. (2000). Affective picture processing: The late positive potential is modulated by motivational relevance. Psychophysiology, 37, 257-261.

Schupp, H. T., Flaisch, T., Stockburger, J., \& Junghöfer, M. (2006). Emotion and attention: Event-related brain potential studies. Progress in Brain Research, 156, 31-51.

Schyns, P. G., \& Oliva, A. (1994). From blobs to boundary edges: Evidence for time-and spatial-scale-dependent scene recognition. Psychological Science, 5, 195-200.

Thorpe, S., Fize, D., \& Marlot, C. (1996). Speed of processing in the human visual system. Nature, 381, 520-522.

Weymar, M., Löw, A., Melzig, C. A., \& Hamm, A. O. (2009). Enhanced long-term recollection for emotional pictures: Evidence from high-density ERPs. Psychophysiology, 46, 1200-1207.

Wichmann, F. A., Sharpe, L. T., \& Gegenfurtner, K. R. (2002). The contributions of color to recognition memory for natural scenes. Journal of Experimental Psychology: Learning, Memory, and Cognition, 28, 509-520. 